\title{
Can tree-ring density data reflect summer temperature extremes and associated circulation patterns over Fennoscandia?
}

\author{
Peng Zhang ${ }^{1}$ (i) $\cdot$ Monica Ionita ${ }^{1,2} \cdot$ Gerrit Lohmann $^{1,2} \cdot$ Deliang $^{\text {Chen }}{ }^{3}$ • \\ Hans W. Linderholm ${ }^{3}$
}

Received: 10 March 2016 / Accepted: 20 September 2016 / Published online: 19 December 2016

(C) The Author(s) 2016. This article is published with open access at Springerlink.com

\begin{abstract}
Tree-ring maximum latewood density (MXD) records from Fennoscandia have been widely used to infer regional- and hemispheric-scale mean temperature variability. Here, we explore if MXD records can also be used to infer past variability of summer temperature extremes across Fennoscandia. The first principal component (PC1) based on 34 MXD chronologies in Fennoscandia explains $50 \%$ of the total variance in the observed warm-day extremes over the period 1901-1978. Variations in both observed summer warm-day extremes and PC1 are influenced by the frequency of anomalous anticyclonic pattern over the region, summer sea surface temperatures over the Baltic, North and Norwegian Seas, and the strength of the westerly zonal wind at $200 \mathrm{hPa}$ across Fennoscandia. Both time series are associated with nearly identical atmospheric circulation and SST patterns according to composite map analysis. In a longer context, the first PC based on 3 millennium-long MXD chronologies in central and northern Fennoscandia explains $83 \%$ of the total variance of PC1 from the 34
\end{abstract}

Electronic supplementary material The online version of this article (doi:10.1007/s00382-016-3452-5) contains supplementary material, which is available to authorized users.

Peng Zhang

Peng.Zhang@awi.de; zp82623@163.com

1 Alfred Wegener Institute, Bussestr. 24, 27570 Bremerhaven, Germany

2 MARUM, University of Bremen, 28359 Bremen, Germany

3 Regional Climate Group, Department of Earth Sciences, University of Gothenburg, Box 460, 40530 Gothenburg, Sweden
MXD chronologies over the period 1901-1978, 48\% of the total variance of the summer warm-day extreme variability over the period 1901-2006, and 36\% of the total variance in the frequency of a summer anticyclonic pattern centered over eastern-central Fennoscandia in the period 1948-2006. The frequency of summer warm-day extremes in Fennoscandia is likely linked to a meridional shift of the northern mid-latitude jet stream. This study shows that the MXD network can be used to infer the variability of past summer warm-day extremes and the frequency of the associated summer anticyclonic circulation pattern over Fennoscandia.

Keywords Tree-ring proxy - Atmospheric circulation · Fennoscandia $\cdot$ Temperature extremes $\cdot$ Jet stream

\section{Introduction}

Changes in the intensity and frequency of summer hightemperature extremes have drawn much attention during recent decades (Schär 2015), mainly due to their large impacts on natural environment, economy and human health (Ciais et al. 2005; Kovats and Kristie 2006). For instance, the European summer heat wave in 2003 resulted in extensive forest fires, crop yield reductions and a high number of casualties (De Bono et al. 2004; Vandentorren et al. 2004). In Scandinavia, heat waves also have been related to public health risks (Rocklöv and Forsberg 2008).

During the 20th century, the frequency of high-temperature extremes (i.e. the number of days when daily maximum/minimum temperature surpasses a threshold) has increased in Europe (Chen et al. 2015), but the instrumental records are often too short for climate change studies. In order to explore any long-term changes in 
high-temperature extremes, their behavior under natural conditions, as well as their relation to other variables in the climate system, such as the large-scale atmospheric circulation, we need to go beyond the instrumental period. Moreover, as temperature extremes are usually closely linked with specific circulation patterns, such as atmospheric blockings (Rimbu et al. 2014; Ionita et al. 2015), studies of long-term extreme variability can also be helpful when assessing the history of certain type of atmospheric circulation patterns in a region.

High-resolution proxies, such as tree-ring data and historical records, have been used to study past temperature extremes in Europe, and have been proven to be useful indicators of temperature extremes (Luterbacher et al. 2004; Xoplaki et al. 2005; Battipaglia et al. 2010; Esper et al. 2012a). Water, light and temperature are important factors for tree growth (Fritts 1976). As high-temperature extreme events in summer usually represent sunny weather conditions (García-Herrera et al. 2010), trees growing under sufficient soil moisture conditions may benefit from such weather conditions. In this respect, Fennoscandia is ideal for studies of past temperature extremes using treering data.

The high-latitude location of the region, as well as the proximity to the North Atlantic Ocean, makes tree growth here in general sensitive to temperature (Schweingruber et al. 1988; Linderholm et al. 2010). This region also hosts a dense tree-ring data network (Seftigen et al. 2015), where particularly the maximum latewood density (MXD) parameter provides high-quality summer or warm-season (AprilSeptember) temperature information (Esper et al. 2012b; Melvin et al. 2013; Helama et al. 2014). Indeed, MXD data has been shown to explain around $60 \%$ of the total variance in observed mean summer temperature in central and northern Fennoscandia over the period 1901-2005 (Esper et al. 2012b; Melvin et al. 2013; Linderholm et al. 2015). However, although tree-ring data from this region have been widely used to infer past local to regional mean temperature variability (e.g. Briffa et al. 1992; Linderholm and Gunnarson 2005; Linderholm et al. 2015), to our knowledge, no systematic study has examined the potential of using these data to infer the variability and frequency of past temperature extremes and their associated atmospheric circulation patterns.

The aims of this work are: (1) to explore if MXD in Fennoscandia can be used as a proxy for the frequency of summer high-temperature extremes and (2) to identify which large-scale atmospheric circulation patterns are associated with these extremes. This paper is organized as follows. Section 2 describes the study area, the data and the methods used; Sect. 3 presents the results which are discussed in Sect. 4, and conclusions are given in Sect. 5.

\section{Data and methods}

\subsection{Study area}

Fennoscandia is located in the northern part of Europe, and comprises Norway, Sweden and Finland. The region stretches about $1800 \mathrm{~km}$ from south to north, and $1400 \mathrm{~km}$ from west to east, thus displaying a variety of different climate conditions. Climate in the north is characterized by harsh winters with a long-lasting snow cover and a short growing season in summer, while climate in the south is featured by mild winters with little or no snow cover, and longer growing season (Linderholm 2006; Linderholm et al. 2008). Climate variability in this region is influenced by a number of circulation patterns in summer such as the East Atlantic, Western Russia and Scandinavia patterns (Irannezhad et al. 2015) and the North Atlantic Oscillation (NAO) on interannual-to-decadal time scales (Hurrell 1995; Rogers 1997; Chen and Hellström 1999; Busuioc et al. 2001; Folland et al. 2009). North Atlantic sea surface temperature (SST) also plays a role on decadal to centennial time scales (Dima and Lohmann 2007).

\subsection{The tree-ring data}

Thirty-four Pinus sylvestris L. (Scots pine) and Picea abies (Norway spruce) MXD chronologies from Fennoscandia were used to explore the relationship with temperature extremes (Fig. 1). Most of the tree-ring data were downloaded from the International Tree-Ring Data Bank (ITRDB,

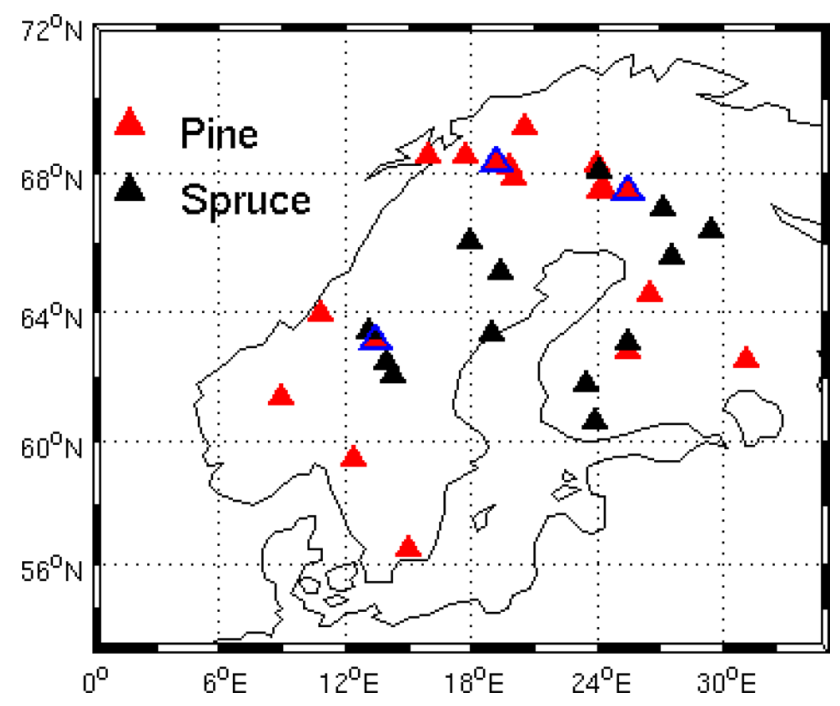

Fig. 1 The map of the study area and the locations of 34 tree-ring MXD chronologies covering the period of 1901-1978. Blue colors mark the locations of three millennium-long chronologies 
https://www.ncdc.noaa.gov/data-access/paleoclimatologydata/datasets/tree-ring; Grissino-Mayer and Fritts 1997), while some of the data from central Sweden were collected between 2011 and 2013 by ourselves (Linderholm et al. 2014, 2015). More information about the tree-ring data used in this study can be found in Table S1 in the supplementary section.

Low-frequency variability ( $>30$ years), including agerelated trend, was removed from each individual MXD series by subtracting a fitted 30-year cubic smoothing spline function. This standardization method makes no assumptions about the shape of the curve to be used for standardization, and the fitted spline curves ranges from linear least square to cubic fit through the data, and thus are flexible in removing non-climatic variance (Cook and Peters 1981) while preserving extreme variability of tree growth. A chronology for each site was produced by averaging all the individually standardized time series. A minimum number of 5 trees was required for representing a reliable chronology. Since a large number of the MXD chronologies in Fennoscandia ended in 1978, the analysis was based on the period 1901-1978. Additionally, three millennium-long chronologies (Jämtland, Torneträsk, Lapland; Table S1), covering the period 1000-2006, were used to examine the possibility to infer the variability in summer temperature extremes in a long-term context.

\subsection{Meteorological data}

Temperature extreme indices were derived from the HadEx2 gridded global dataset (Donat et al. 2013). This dataset is based on daily maximum and minimum temperature and precipitation observations from over 7000 temperature and 11,000 precipitation meteorological stations across the globe, and extreme indices were then calculated for the periods when the records were available for each station. Then, station-based monthly and annual extreme indices were interpolated onto a $3.75^{\circ}$ longitude $\times 2.5^{\circ}$ latitude grid over the period 1901-2010 using a modified version of Shepard's angular distance weighting (ADW) interpolation algorithm (Shepard 1968). From this dataset, 17 temperature and 12 precipitation indices were calculated using a consistent approach recommended by the World Meteorological Organization (WMO) Expert Team on Climate Change Detection and Indices (ETCCDI, http://wcrp-climate.org/etccdi).

To explore the relationship between MXD and extreme events, we used six extreme-temperature indices: warm days (TX90p), cool days (TX10p), warm nights (TN90p), cool nights (TN10p), warm spell duration index (WSDI) and number of summer days (SU). TX90p is defined as the percentage of days when daily maximum temperature is higher than the 90th percentile; TX10p is defined as percentage of days when daily maximum temperature is lower than the 10th percentile; TN90p is defined as the percentage of days when daily minimum temperature is higher than the 90th percentile; TN10p is defined as the percentage of days when daily minimum temperature is lower than the 10th percentile. WSDI is defined as annual count of days with at least 6 consecutive days when daily maximum temperature is higher than 90th percentile. SU is defined as annual count of days when daily maximum temperature is higher than $25^{\circ} \mathrm{C}$. All the time series of the extreme indices are the results of making annual arithmetic average of the values at 25 grid cells over Fennoscandia.

Monthly data of geopotential height (Z850), zonal (U850) and meridional wind speed (V850) at the $850 \mathrm{hPa}$ level and zonal wind speed at the $200 \mathrm{hPa}$ level (U200) were taken from the NOAA-CIRES 20th century reanalysis version V2c dataset (Whitaker et al. 2004; Compo et al. 2006, 2011). The data was obtained from the NOAA web site at http://www.esrl.noaa.gov/psd/. This dataset covers the period 1851-2011, and has a spatial resolution of $2^{\circ}$ longitude $\times 2^{\circ}$ latitude. SST data was taken from the Extended Reconstructed Sea Surface Temperature version 4 (ERSSTv4) (Huang et al. 2015; Liu et al. 2015). This dataset is a global monthly SST dataset derived from the International Comprehensive Ocean-Atmosphere Dataset (ICOADS) covering the period 1854-2015 with a spatial resolution of $2^{\circ}$ longitude $\times 2^{\circ}$ latitude.

\subsection{Statistical methods}

Field maps of mean values and standard deviations (SD) of temperature extremes over 1901-2010 were used to investigate the spatial characteristics of the temperature extremes over Fennoscandia, focusing on the average of the summer season (June through August, JJA). To determine the spatial coherence of the temperature extremes, Pearson correlation coefficients between each pair of grid cells over Fennoscandia were calculated. The correlation coefficients were plotted against the distance between the grid cells to show the Correlation Decay Distance (CDD) of temperature extremes in the region (Briffa and Jones 1993).

To extract the common signal of the Fennoscandian MXD data, an Empirical Orthogonal Function (EOF) analysis (von Storch and Zwiers 2001) was applied to the data from the MXD network. The aim of the EOF analysis technique is to find a new set of variables that captures most of the variance of the data through a linear combination of the original variables. This method extracts the leading spatial modes of the MXD network and their corresponding temporal variability by mapping the temporal variance of each individual treering chronology onto orthogonal spatial patterns.

Field maps of the correlations between the PCs of the MXD network and gridded temperature extreme indices were used to explore the spatial associations. The relationships were then 
quantified by calculating the correlations between the PCs and the mean value of the temperature extreme series for the whole Fennoscandia. We only present the field maps of the correlations between the MXD PC1 and the TX90p index in the results, since the MXD PC1 has the highest correlation with TX90p compared to that with other indices, and the MXD PC2 does not show any significant relationships with any of the indices in summer. When calculating seasonal mean values of the monthly temperature extremes, we regarded the seasonal mean value in a specific year as a missing value if any of the 3 months had missing values. Grid cells with more than $10 \%$ missing seasonal values were excluded from the analysis.

To identify large-scale atmospheric circulation and SST patterns associated with observed temperature extremes and the MXD PC anomalies, we evaluated the differences of composite maps for geopotential height at $850 \mathrm{hPa}$ level, wind field at $850 \mathrm{hPa}$ level and zonal wind field at $200 \mathrm{hPa}$ level for the North Atlantic region, for JJA, between anomalously-high (normalized PCs/extreme index $>0.8 \mathrm{SD}$ ) and anomalouslylow (normalized PCs/extreme index $<-0.8 \mathrm{SD}$ ) years. We also only present the composite-map analysis results based on the MXD PC1 and the TX90p index. The selection of the thresholds (i.e. $\pm 0.8 \mathrm{SD}$ ) was a compromise between the strength of the series anomalies and the number of years (around 20\% of the total years). In the observational series (1901-2010), 21 anomalously-high and 24 anomalously-low JJA TX90p years were identified, while in the MXD PC1 series (1901-1978), 14 anomalously-high and 18 anomalously-low MXD PC1 years were identified (See Table S2).

\subsection{Wavelet analysis}

Wavelet analysis was used to analyze the temporal structure of MXD PC1. Wavelet analysis decomposes a time series into a time-frequency space, and it is thus possible to determine the dominant modes of variability, and how these modes vary in time (Maraun et al. 2007). The wavelet analysis used in this study follows the methods of Maraun and Kurths (2004) and Maraun et al. (2007), and the Morlet wavelet was chosen as wavelet basis. The $95 \%$ statistical significance level of the wavelet power spectrum was determined against a white noise null hypothesis using a pointwise significance test (Maraun and Kurths 2004; Maraun et al. 2007; Torrence and Compo 1998).

\section{Results}

\subsection{Temporal and spatial characteristics of Fennoscandian temperature extremes}

Figure 2a shows the mean TX90p in the whole of Europe over the period 1901-2010. The highest frequencies
(>14\%) are observed in parts of eastern Europe including southeastern Fennoscandia, while moderate frequencies (11-14\%) are found across eastern and central Europe and central and northern Fennoscandia. Low TX90p frequencies $(<11 \%)$ are observed in regions with more maritime influences: southern Fennoscandia, the British Isles, northern continental Europe and the Iberian Peninsula. Figure $2 b$ shows that the largest year-to-year variability in TX90p are found in parts of eastern continental Europe and south-eastern Fennoscandia. Over central and northern Fennoscandia, the interannual variability is less pronounced than in parts of eastern Europe, but still higher than most other regions in Europe. Figure 2c shows the TX90p CDD for all the 25 grid cells over Fennoscandia, where each curve is fitted to the scatter plots of the correlations between one particular grid cell and the other 24 grid cells. The results show that the variability of TX90p in one grid cell can explain more than $50 \%$ of the variance of the variability in other grid cells within a radius of $800 \mathrm{~km}$ over Fennoscandia. In Fig. 2c, all the correlation coefficients are significant at the $95 \%$ significance level.

\subsection{Spatial and temporal patterns of Fennoscandian MXD chronologies}

Figure 3a shows EOF1 of the Fennoscandian MXD network, which explains around $57 \%$ of the total variance of the MXD variability. The first EOF is characterized by positive loadings over the whole of Fennoscandia. The loadings indicate that MXD data from central and northern Fennoscandia contribute the most to the total explained variance. However, the monopolar feature of EOF1 shows the homogeneity of the MXD data over Fennoscandia, reflecting a common forcing of MXD formation of both Scots pine and Norway spruce. The corresponding time series of EOF1 (PC1), shows clear interannual variability (Fig. 3b), where two notable positive anomalies are found in 1901 and 1937, and three distinct negative anomalies are found in 1902, 1923 and 1962. Figure 4a shows the second leading mode (EOF2) which explains around 9\% of the total variance and displays a northwest to southeast oriented dipole-like structure. Also PC2 shows clear interannual variability (Fig. 4b), where the variability seemingly increases after $\sim 1950$.

\subsection{The relationship between MXD and temperature extremes in Fennoscandia}

Figure 5 shows the spatial correlations between the MXD PC1 and seasonal (i.e. December-January-February (DJF), March-April-May (MAM), June-July-August (JJA) and September-October-November (SON)) TX90p indices over Fennoscandia. The MXD PC1 is positively 
(a) JJA TX90p mean

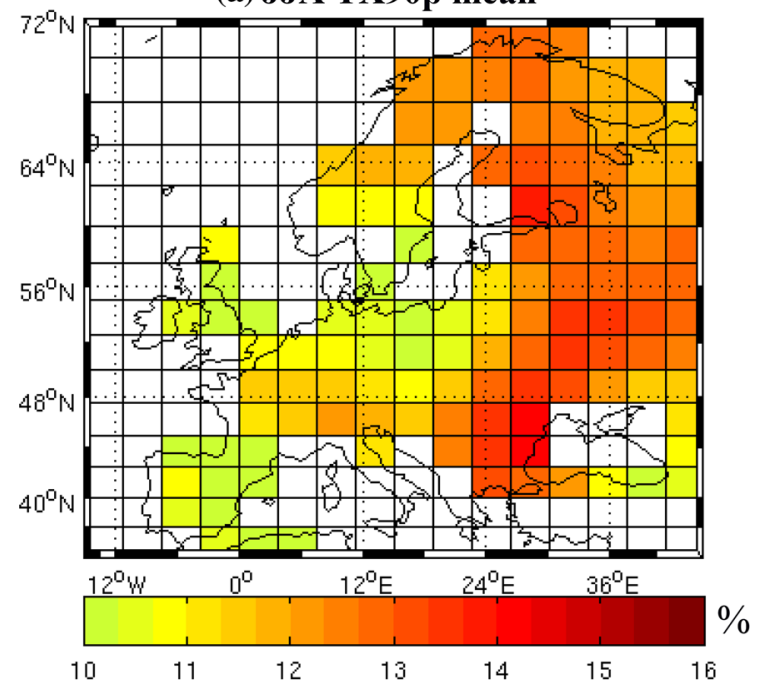

(b) JJA TX90p SD

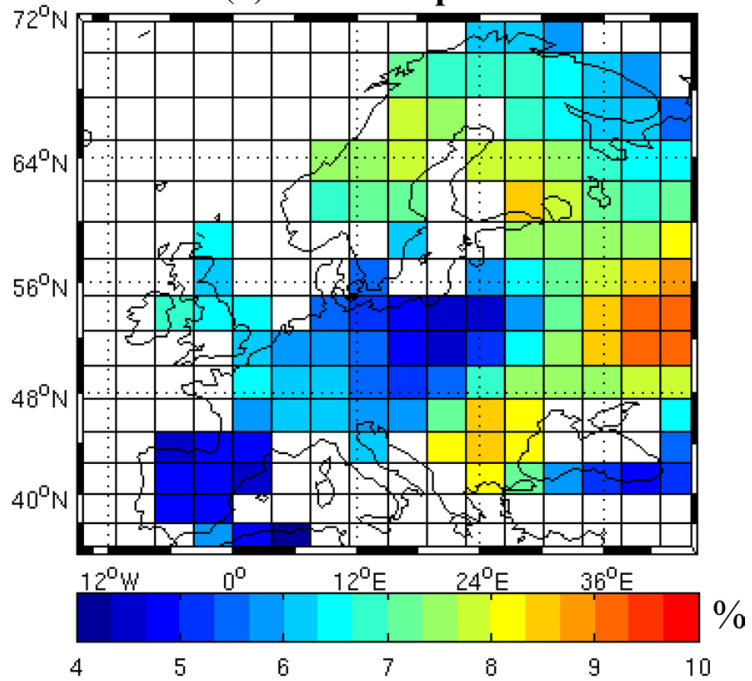

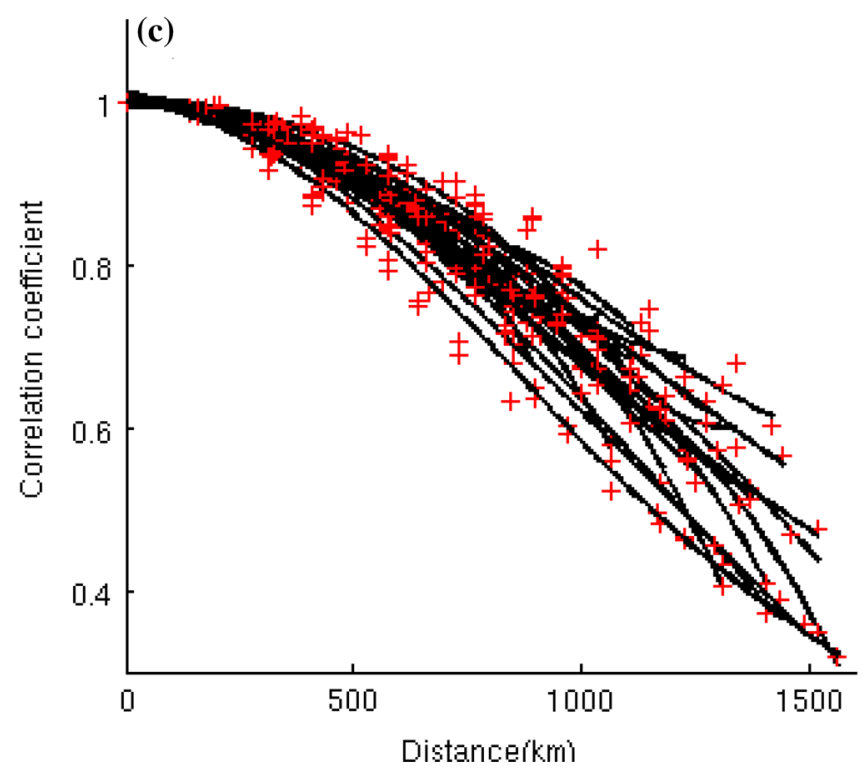

Fig. 2 The field maps of the a mean and the $\mathbf{b}$ standard deviation of the June-August (JJA) warm-day extreme index (TX90p) derived from the gridded dataset HadEx2 (Donat et al. 2013) over Europe during 1901-2010, and $\mathbf{c}$ the correlation between the TX90p time series from the gridded extreme-index field, as a function of distance

correlated with TX90p at the $95 \%$ significance level in MAM and JJA over the whole Fennoscandia and the north-eastern part of Europe. However, the relationship in JJA is much stronger compared to the one in MAM. The strongest correlations are found over northern Fennoscandia, reaching values as high as 0.8 . When PC1 is correlated with DJF and SON warm-day indices, significant correlations are found over the Iberian Peninsula and the southern part of Fennoscandia, respectively. However, for both seasons (DJF and SON) the correlation coefficients are quite small (around 0.2-0.3), showing a weak between the grid cells. Each black curve fits the scatter plot of correlation coefficients (red+) between one grid cell and other 24 grid cells over Fennoscandia, indicating the correlation decay distance in this region. All the correlation coefficients shown here are significant at the $95 \%$ significance level

relationship between PC1 and the DJF and SON warmday extremes.

To explore the potential of the MXD data to infer past extreme temperature variability and to facilitate comparison of the different indices, we calculated Fennoscandian (based on the 25 grid cells covering the region) JJA mean temperature extreme indices, and compared them with PC1. The correlation coefficient between PC1 and the Fennoscandian JJA mean TX90p is $0.71(P<0.01)$ (Fig. 6), indicating that MXD PC1 explains 50\% of the variance of the TX90p variability over the period 1901-1978. 
Fig. 3 a The spatial pattern of the first EOF mode of the Fennoscandian tree-ring MXD network, and $\mathbf{b}$ the time series of the first principal component (PC1) corresponding to the first EOF mode explaining $57 \%$ of the total variance

Fig. 4 As Fig. 3, but for a EOF2 and b PC2 (9\%)

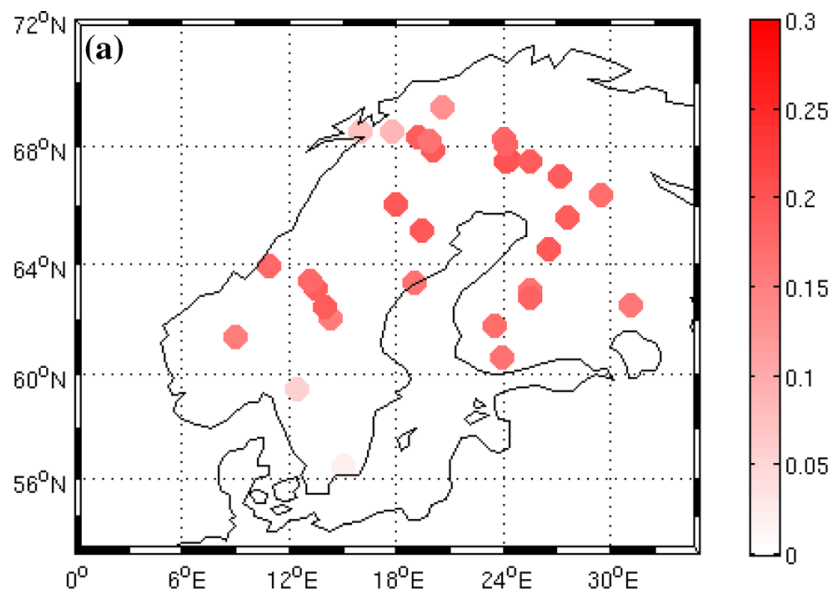

(b) PC1 of Fennoscandian tree-ring MXD network (1901-1978)
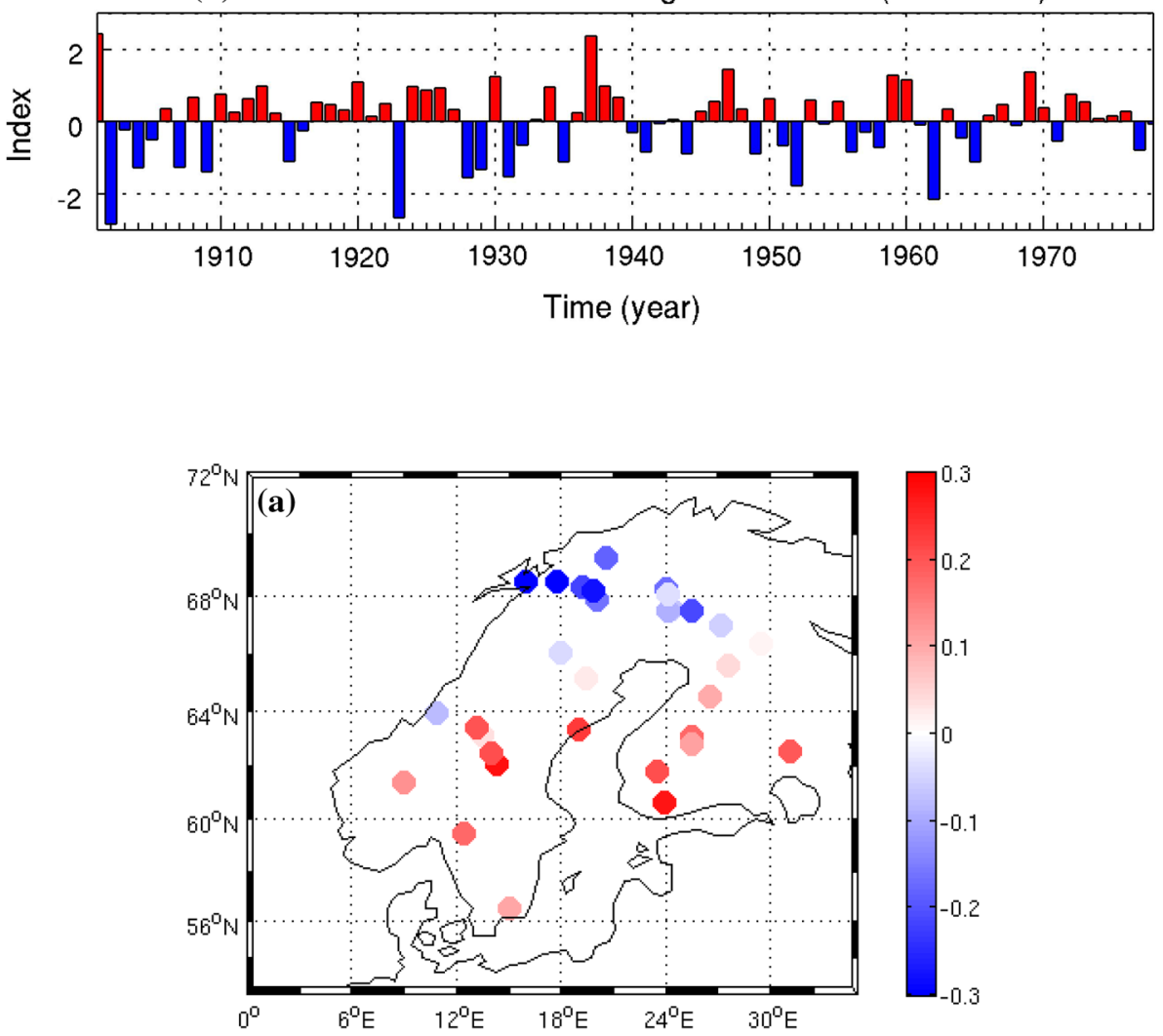

(b) PC2 of Fennoscandian tree-ring MXD network (1901-1978)

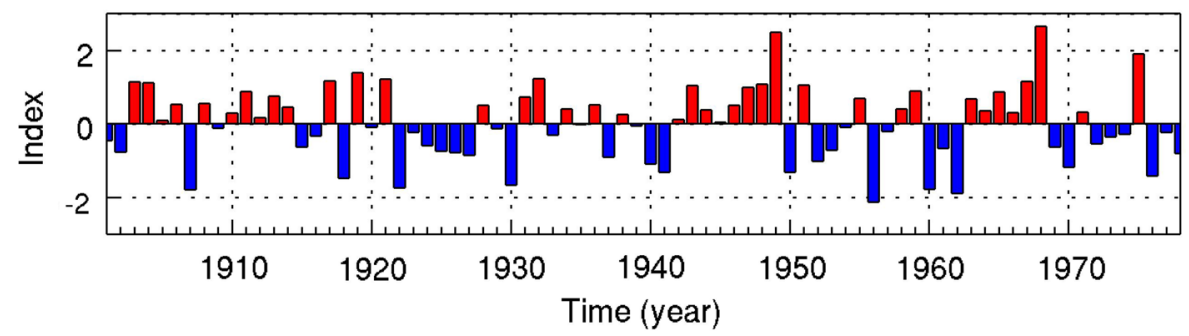



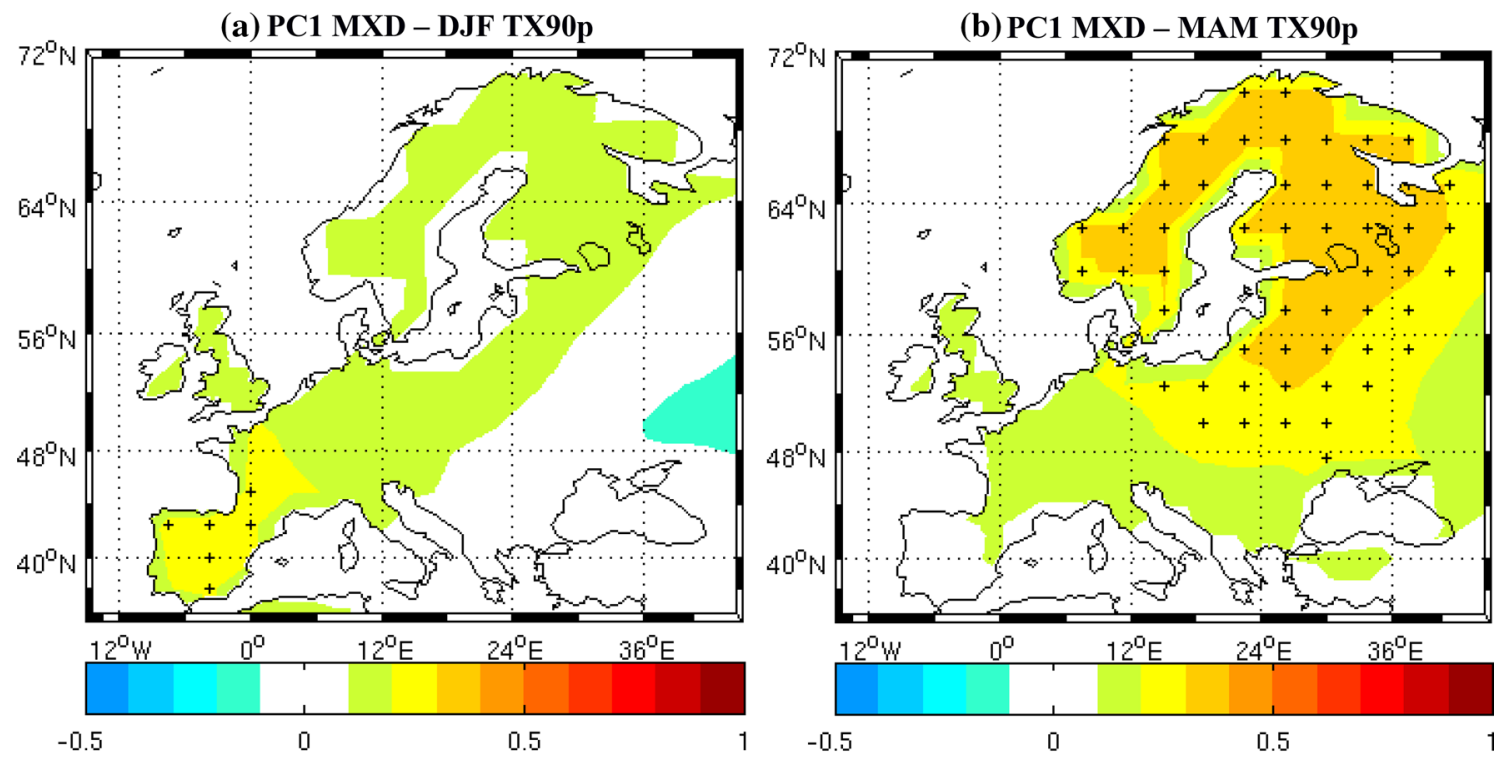

(c) PC1 MXD - JJA TX90p

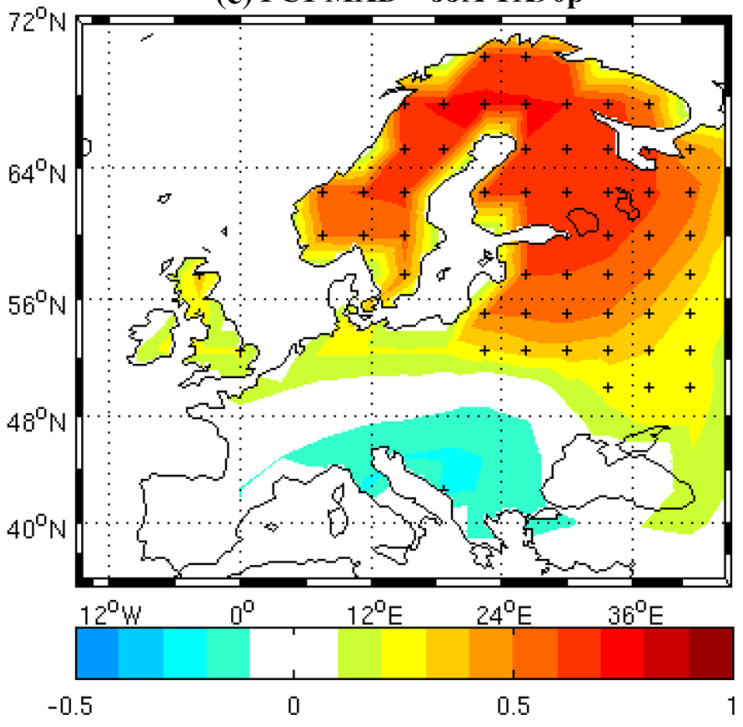

Fig. 5 Correlation maps between the $\mathrm{PC} 1$ of the Fennoscandian tree-ring MXD network and a preceding December-present February (DJF), b March-May (MAM), c June-August (JJA) and d September-November (SON) warm-day extreme indices derived from the

Correlations are also calculated between PC1 and other seasonal or annual temperature extreme indices depending on if the index has a seasonal resolution (e.g. TX90p, TX10p, TN90p and TN10p) or an annual resolution (e.g. WSDI and SU). In Table 1, the results show that all the summer temperature extreme indices are significantly correlated with the tree-ring MXD PC1 for both MAM and JJA at the $99 \%$ significance level. However, the JJA indices show much stronger relationships with PC1 compared

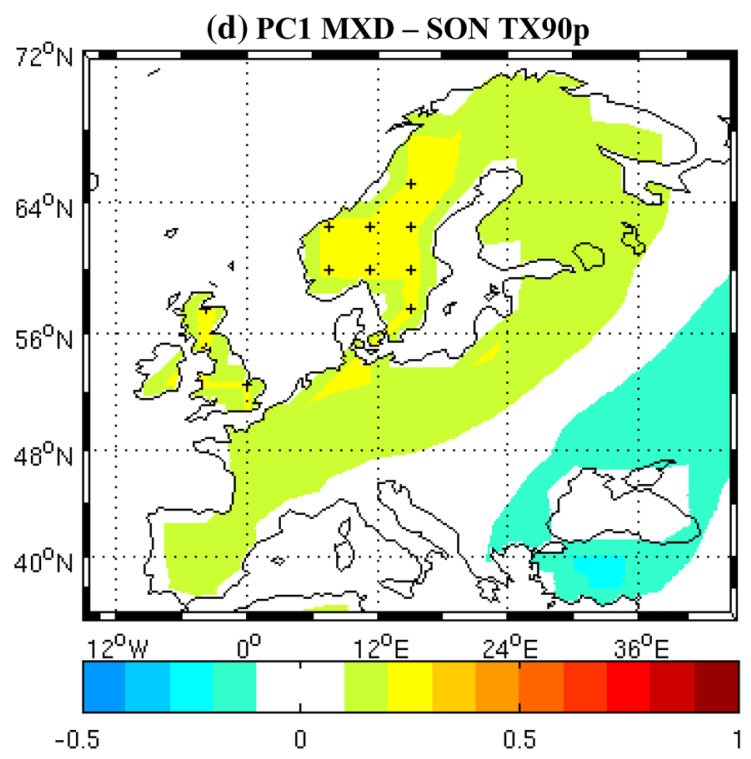

gridded dataset HadEx2 (Donat et al. 2013) over the period 19011978. Plus sign marks the grid cells where the correlations are significant at the $95 \%$ significance level

to the MAM indices. The strongest relationship is found between the PC1 and the JJA warm-day index. PC1 also shows significant relationships with the two annuallyresolved temperature indices (i.e. WSDI and SU) at the 99\% significance level. The correlations between MXD PC2 and the six temperature indices are also shown in Table 1. The results show that no significant relationships are found between the PC2 and the summer/annual temperature extreme indices. 
Fig. 6 Fennoscandian MXD PC1 (red) plotted against mean JJA TX90p for Fennoscandia (blue) derived from the gridded dataset HadEx2 (Donat et al. 2013)

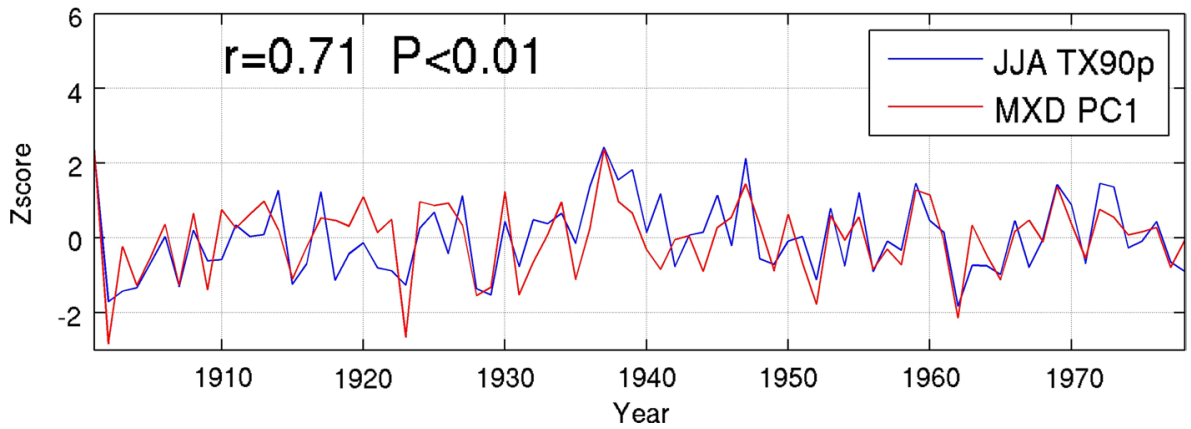

Table 1 The correlation coefficients between the Fennoscandian tree-ring MXD PC1 and PC2 time series and four seasonal and two annual temperature extreme indices time series derived from the HadEx2 dataset (Donat et al. 2013)

\begin{tabular}{|c|c|c|c|c|c|c|c|c|c|c|}
\hline \multirow[t]{2}{*}{ Extreme index } & \multicolumn{5}{|c|}{ PC1 MXD (57\%) } & \multicolumn{5}{|c|}{ PC2 MXD (9\%) } \\
\hline & DJF & MAM & JJA & SON & Ann & DJF & MAM & JJA & SON & Ann \\
\hline TX90p & 0.15 & $0.36 * * *$ & $0.71 * * *$ & $0.21 *$ & - & 0.08 & 0.13 & 0.01 & $0.26 * *$ & - \\
\hline TX10p & -0.02 & $-0.40 * * *$ & $-0.70 * * *$ & $-0.19 *$ & - & -0.16 & -0.08 & 0.02 & -0.08 & - \\
\hline TN90p & 0.15 & $0.37 * * *$ & $0.60 * * *$ & 0.13 & - & 0.07 & $0.21 *$ & -0.04 & $0.20 *$ & - \\
\hline TN10p & -0.02 & $-0.40 * * *$ & $-0.55 * * *$ & -0.11 & - & -0.16 & -0.13 & 0.14 & -0.04 & - \\
\hline WSDI & - & - & - & - & $0.48 * * *$ & - & - & - & - & 0.17 \\
\hline SU & - & - & - & - & $0.62 * * *$ & - & - & - & - & 0.08 \\
\hline
\end{tabular}

The extreme indices time series are the mean values of the data from the grid cells over Fennoscandia

*** Means $99 \%$ significance level; ** means $95 \%$ significance level; * mean 90\% significance level. The percentages indicate the explained variance of the PCs on the total variance of the Fennoscandian tree-ring MXD network

\subsection{Influence of atmospheric circulations and North Atlantic SST on the TX90p and the MXD variability}

Since the interannual variability of PC1 is closely associated with the studied JJA temperature indices, especially TX90p, MXD can be regarded as a good indicator of the frequency of JJA temperature extremes over the study region. The typical circulation and SST anomalies associated with anomalous JJA TX90p indices reveal the largescale atmospheric circulation and the SST patterns that favor extreme conditions. Figure 7a shows a composite map of JJA geopotential height (Z850) and wind vectors (U850 and V850) at $850 \mathrm{hPa}$ for high- $(+0.8 \mathrm{SD})$ minus low- $(-0.8$ SD) index years of TX90p. High TX90p values in JJA are associated with a center of positive Z850 anomalies over the Fennoscandia Peninsula and over the northeast coast of North America and a center of negative Z850 anomalies over Greenland. This pattern is associated with an anomalously strong anticyclonic circulation favoring high-temperatures and reduced precipitation over Fennoscandia. The variability of the frequency of the JJA anticyclonic circulation pattern explains around $53 \%$ of the variance of the frequency of JJA warm-day extremes over the period 1948-2010 (Fig. S1a). Figure 7b shows the same as Fig. 7a, but for MXD PC1, and displays nearly identical features as those for TX90p.

Figure 8a shows a composite map of JJA North Atlantic SST anomalies during high- minus low-TX90p-index years. High TX90p frequencies are associated with strong positive SST anomalies over the North Sea and (particularly) the Baltic Sea and outside the northeast coast of North America, extending towards the Azores. Turning to MXD PC1, similar patterns are observed as those for the TX90p regarding the associations with positive SST anomalies (Fig. 8b). However, MXD PC1 is more strongly associated with negative SST anomalies over the southern part of Greenland and the subtropical part of the North Atlantic Ocean, compared to TX90p.

In the Northern Hemisphere, strong anticyclonic circulation is usually associated with an intense high-altitude zonal wind over northern part of the region (Tsou and Smith 1990; Lupo and Smith 1995). Therefore, we examined the link between TX90p and zonal wind speed at $200 \mathrm{hPa}$ (U200). Figure 9a shows a composite map of the difference of JJA zonal wind speed at $200 \mathrm{hPa}$ in high and low TX90p index years. In summer, high TX90p indices are associated with enhanced $200 \mathrm{hPa}$ westerly zonal winds over the northern part of Fennoscandia, northeast of the North American continent, the 
Fig. 7 The difference of the composite maps of JuneAugust (JJA) geopotential height (shaded, Z850) and the wind vectors at $850 \mathrm{hPa}$ (arrows) derived from the monthly NOAA-CIRES twentieth century reanalysis version V2c dataset (Whitaker et al. 2004; Compo et al. 2006, 2011) between high-and low-index years of a the JJA TX90p over the period 1901-2010 (cf. Fig. 6) and b the Fennoscandian tree-ring MXD PC1 over the period 1901-1978. High- and low-index years are defined as years with values larger and smaller than the 0.8 times of the series standard deviation respectively. High- and lowindex years are summarized in Table S2 (a) JJA TX90p - JJA Z850 and wind at $850 \mathrm{hPa}$

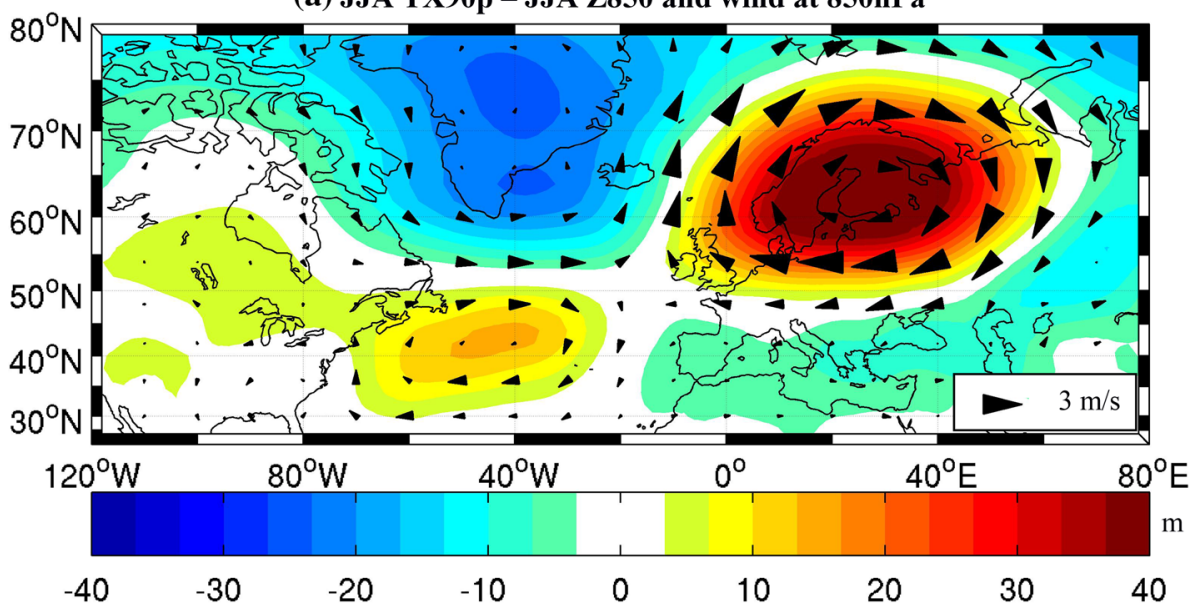

(b) PC1 MXD - JJA Z850 and wind at $850 \mathrm{hPa}$

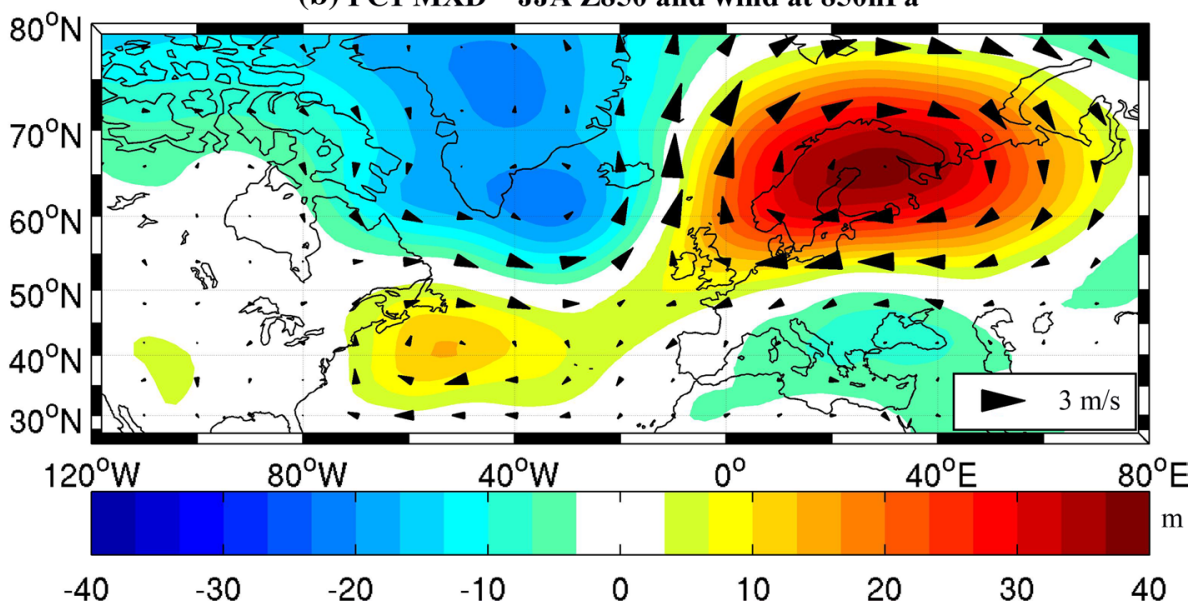

Mediterranean region and western Central Asia. Weakened westerly zonal winds at $200 \mathrm{hPa}$ are found in a belt stretching from the eastern part of North America, across the central North Atlantic, the British Isles, the central part of Europe, the southern part of Fennoscandia and the western part of Russia. Regarding MXD PC1 (Fig. 9b), the approximately same pattern of the zonal winds at $200 \mathrm{hPa}$ is found as for the TX90p, although the pattern is slightly less pronounced.

The differences of JJA zonal wind speed at $200 \mathrm{hPa}$ between high and low TX90p index/MXD PC1 years are distinct (Fig. 9a ,b). However, when the composite maps of the zonal wind speed during the high or low TX90p/MXD PC1 years are compared with the zonal wind speed climatology, we do not see distinct differences (Fig. 10); only small differences still can be identified. From Fig. 10a, we see that increased frequency of TX90p is related to stronger westerly winds over the northeast coast of North America and east of the Caspian Sea, and a slightly northward shift of the jet stream over mid-latitude North America and the North Atlantic Ocean, and a slightly southward shift over the western and the southern part of Europe, compared to climatology (the contour lines). In this case, a high-altitude wind flow is likely to diverge from main track of the jet stream, and form an intensive westerly wind center north of Fennoscandia. From Fig. 10b, we can see that low TX90p indices are associated with a slightly southward shift of the jet stream over the mid-latitude North American continent and the North Atlantic Ocean, and a northward shift over the western and the central part of Europe, compared to climatology (the contour lines). The westerly winds centered over the northeast coast of North America and the eastern part of the Caspian Sea also show a reduction in their strength. Likely, these features are associated with a northward displacement of storm tracks in the former case and a southward displacement in the latter. Figure 10c and d are the same as Fig. 10a and $b$, but based on MXD PC1. We can see similar features as those based on JJA TX90p, which implies that the variability of MXD PC1 reflects meridional shifts in the northern mid-latitude jet stream and changes in the strength of the westerly wind centers. However, the magnitude of the shifts/ changes are smaller than those associated with JJA TX90p 
(a) JJA TX90p - JJA SST

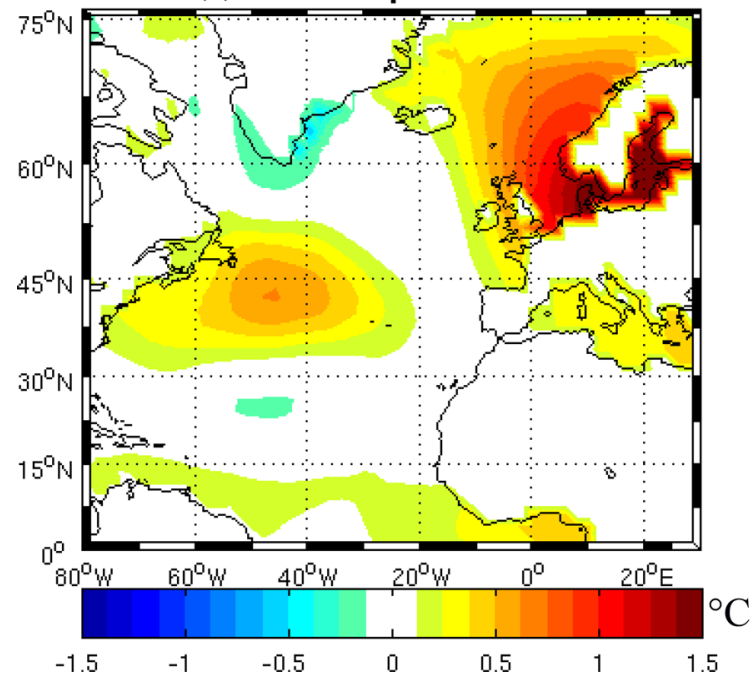

(b) PC1 MXD - JJA SST

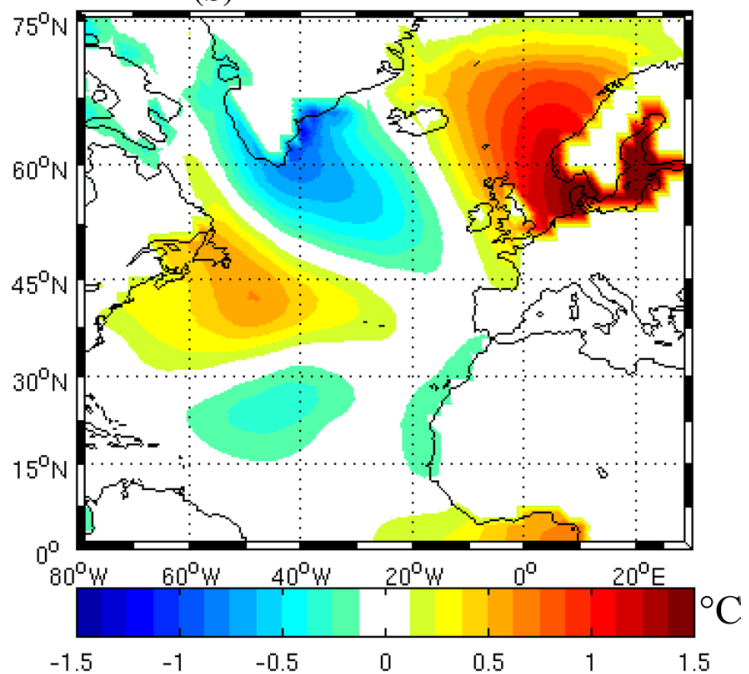

Fig. 8 As Fig. 7, but for SST derived from the gridded dataset ERSSTv4 (Huang et al. 2015; Liu et al. 2015)

Fig. 9 As Fig. 7, but for zonal wind speed at $200 \mathrm{hPa}$ derived from the monthly NOAACIRES twentieth century reanalysis version $\mathrm{V} 2 \mathrm{c}$ dataset (Whitaker et al. 2004; Compo et al. 2006, 2011) (a) JJA TX90p - JJA zonal wind at $200 \mathrm{hPa}$

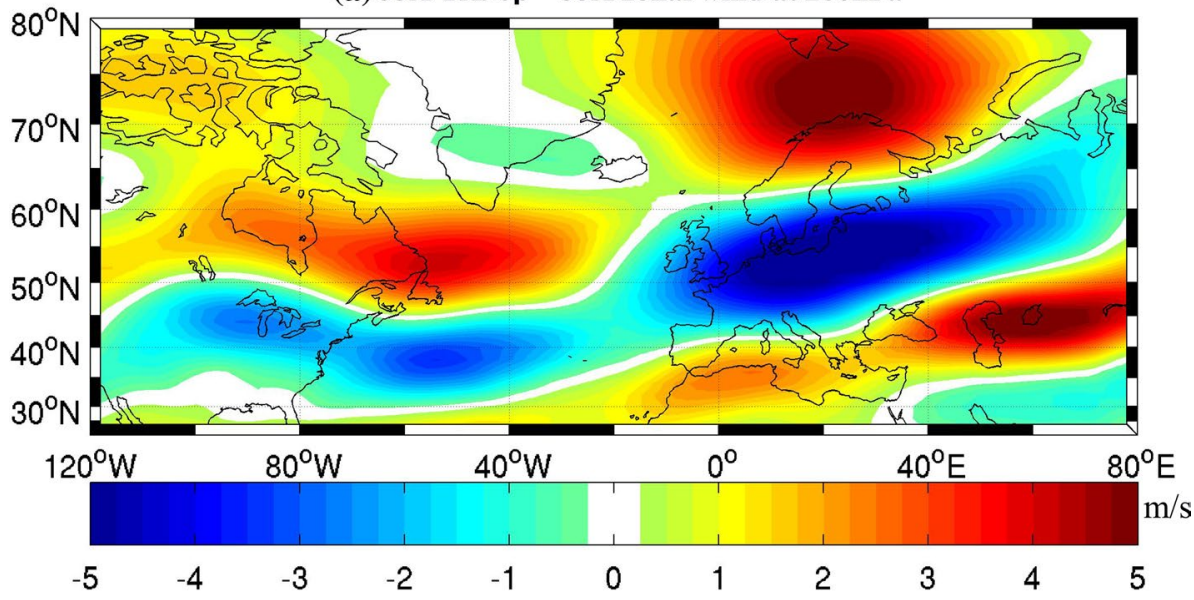

(b) PC1 MXD - JJA zonal wind at 200hPa

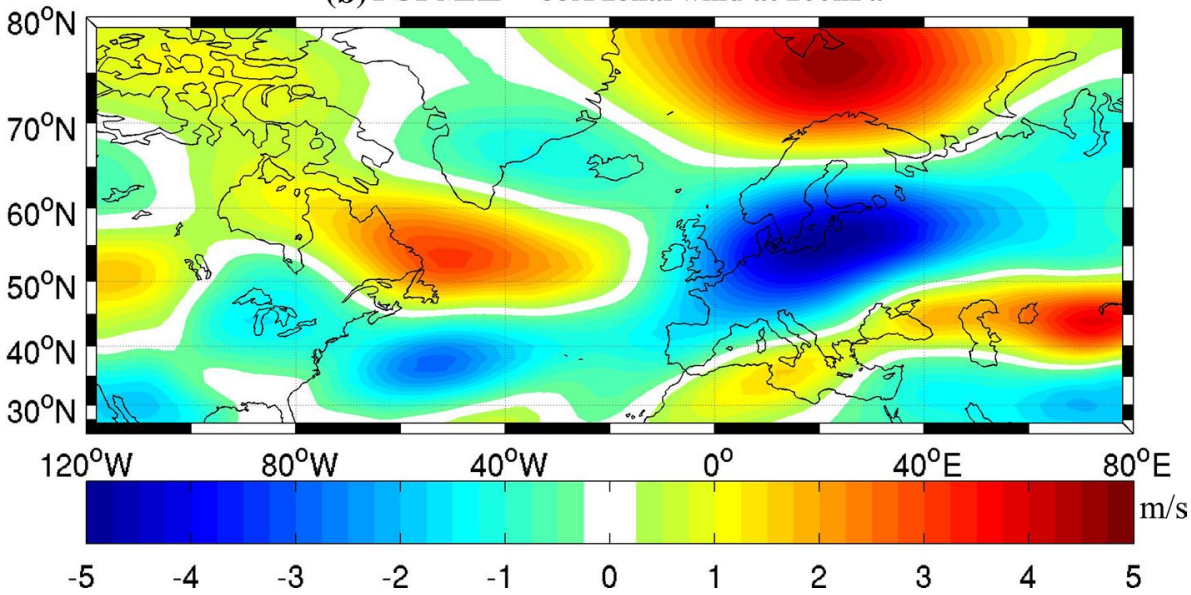


Fig. 10 The composite maps of the zonal wind speed at 200 hpa in the positive/negativeanomalous years of $(\mathbf{a}) /(\mathbf{b})$ the June-August (JJA) warm-day temperature extreme index (Donat et al. 2013) over the period $1901-2010$ and $(\mathbf{c}) /(\mathbf{d})$ the Fennoscandian tree-ring MXD PC1 over the period 1901-1978. The anomalous years were defined as the years when values were bigger (positive) or smaller (negative) than the 0.8 times of the series standard deviation. The contour lines show the climatology of the JJA zonal wind speed at $200 \mathrm{hPa}$ (Whitaker et al. 2004; Compo et al. 2006, 2011) during the period 1901-2010 (a, b) and 1901-1978 (c, d). Numbers on the contour lines show the wind speed on those contour lines (a) Anomalously-high JJA TX90p - JJA zonal wind at 200hPa

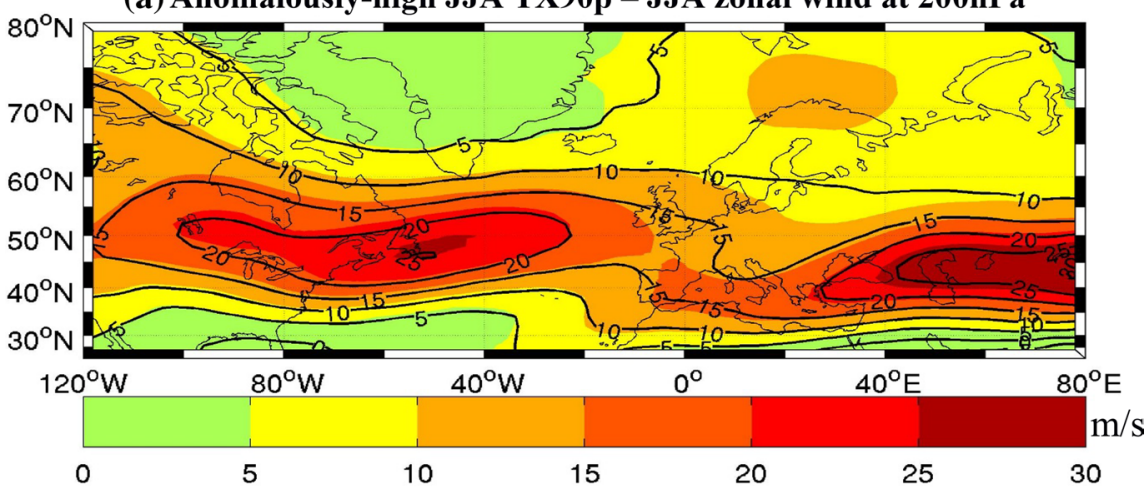

(b) Anomalously-low JJA TX90p - JJA zonal wind at 200hPa

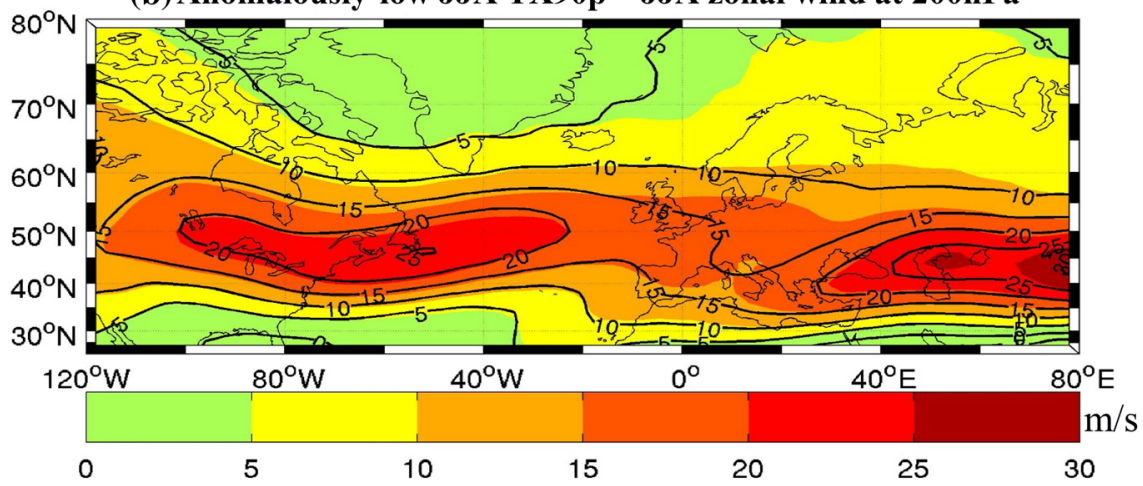

(c) Anomalously-high MXD PC1 - JJA zonal wind at 200hPa

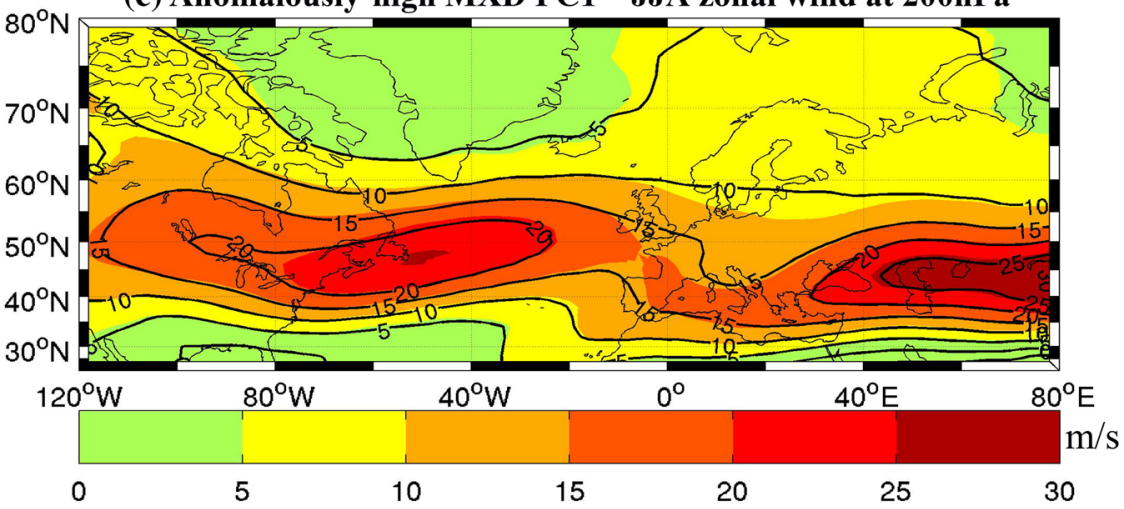

(d) Anomalously-low MXD PC1 - JJA zonal wind at 200hPa

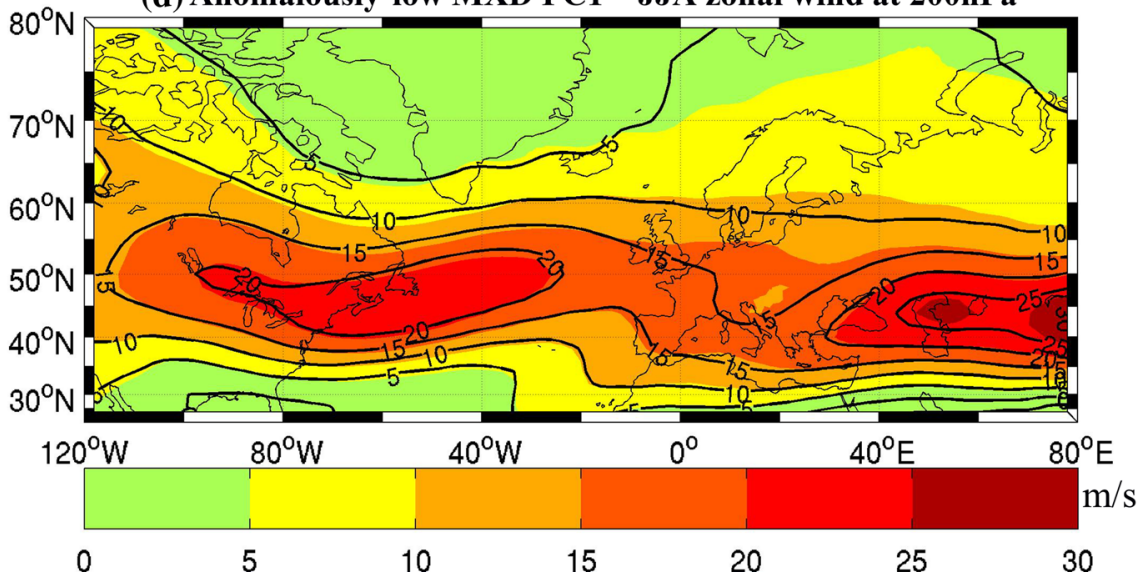


(Fig. 10a, b). Over the period 1901-2006, 23 anomalouslyhigh and 26 anomalously-low MXD PC1 years are identified (See Table S2).

Next, we assess the potential to derive summer temperature extremes from MXD data in a millennium context. Since there are only a few MXD chronologies spanning the last 1000 years in Fennoscandia, we first examine if these chronologies are representative of the full MXD network used in the 20th century analysis. We use three MXD chronologies from Jämtland (west central Sweden, Zhang et al. 2016), Torneträsk (northernmost Sweden, Melvin et al. 2013) and a chronology mainly based on data from Finnish Lapland (Esper et al. 2012b). Comparing PC1 from the 3 millennium-long chronologies with $\mathrm{PC} 1$ from the large MXD network (34 chronologies), it is clear that they are very similar (Fig. 11a): PC1 of the 3 millenniumlong MXD chronologies explains around $83 \%$ of the variance in PC1 of the network. Consequently, we made the assumption that also the long MXD PC1 can be regarded as a representative of TX90p, as well as the frequency of the corresponding anticyclonic circulation pattern in a millennium context. Further analysis shows that the variability of MXD PC1 (based on 3 millennium-long MXD chronologies) explains around $36 \%$ of the variance in the frequency of the JJA anticyclonic circulation pattern (identified using Lamb classification method (Lamb 1950) and adopted to Scandinavia by Chen (2000)) over the period 1948-2006 (Fig. S1b). Figure 11b shows the smoothed (using 21-year Gaussian filter) MXD PC1 for the last 1000 years. The wavelet analysis indicates that the decadal variability is significant during the last millennium, and the variability is more pronounced after $\sim 1500$ (Fig. 11c).

\section{Discussion}

JJA TX90p in Fennoscandia has shown a positive trend during the 20th century (Moberg et al. 2006; Chen et al. 2015). Donat et al. (2013) investigated the spatial pattern of this index, and found that the positive trend in Fennoscandia was generally weaker than those over the central and southern parts of Europe over the period 1951-2010. However, Cornes and Jones (2013) found that the trends over Fennoscandia, the central and southwestern parts of Europe were similar over the period 1980-2011. This study focused on the mean and standard deviation of JJA TX90p across Europe over the period 1901-2010. We show that Fennoscandia has a similar frequency of JJA warm-day extreme occurrences as central Europe (Fig. 2a), and that the variance of the frequency is larger compared to central Europe (Fig. 2b). Moreover, there is a homogenous pattern in TX90p variability across Fennoscandia, as shown by an average CDD of ca. $800 \mathrm{~km}$ (Fig. 2c). This is consistent with the finding that the variability of mean summer temperature is coherent over much of Fennoscandia (Gouirand et al. 2008; Björklund 2014).

The strongest correlation between MXD PC1 and JJA TX90p are found in northern Fennoscandia (Fig. 5). This corresponds to the fact that MXD in northern Fennoscandian conifers contains a stronger summer temperature signal compared to other regions (e.g. the northern part of Europe) (Linderholm et al. 2015). Not surprisingly, the strongest associations are found between MXD and the studied temperature extreme indices during summer, but significant correlations are also found for the spring season (Table 1). The latter is most likely due to the included influence of temperatures in April and May on MXD variability (Conkey 1986).

Figure 7a shows that JJA temperature extremes are associated with anticyclonic circulation anomalies over Fennoscandia. Summer high-temperature extremes are usually related to persistent anticyclonic weather patterns favoring clear sky and weak wind (Black et al. 2004; Pfahl 2014). In these conditions, more solar insolation can reach and warm the land surface, which subsequently increases the surface air temperature, and weak wind conditions can trap warm air (Black et al. 2004). As high summer temperature favors the formation of dense latewood in conifers in tree-line areas across Fennoscandia (Gunnarson et al. 2011; Melvin et al. 2013; Helama et al. 2014; Zhang et al. 2016), it is not surprising that MXD PC1 is also associated with anticyclonic weather patterns (Fig. 7b). Regional circulation patterns influences surface weather conditions, and contribute to the changes in extreme-temperature trends (Horton et al. 2015). Over the eastern part of Fennoscandia, surface air temperature variability has been found to be closely linked to a number of atmospheric circulation patterns. During summer, the mean temperature is significantly related to the East Atlantic pattern (Irannezhad et al., 2015). In central Scandinavia, anticyclonic circulation patterns have been found corresponding to warm and dry weather conditions during summer (Antonsson et al. 2008). Previous studies also show close relationships between European high-temperature extremes and atmospheric blockings at sub-seasonal time scales (Carril et al. 2008). Here, we quantify the relationship between Fennoscandian JJA warm-day extreme and large-scale atmospheric circulation patterns, and we find that an increase in the frequency of the objectively-defined anticyclonic circulation patterns in summer leads to an increase in the frequency of JJA warmday extremes and higher-than-normal MXD PC1 values in Fennoscandia (Fig. S1). This indicates that the MXD PC1 can be used to infer the variability of the frequency of the JJA anticyclonic circulation pattern in Fennoscandia.

Moreover, Fig. 8a indicates that JJA warm-day extremes are associated with anomalous high SSTs over 
Fig. 11 a The Fennoscandian tree-ring MXD PC1 based on the 34 chronologies covering common period 1901-1978 (red) and the 3 millennium-long chronologies having common period 1000-2006 (blue), b the smoothed MXD PC1 (smoothed using 21-year Gaussian filter) over the period 1000-2006, and $\mathbf{c}$ the local wavelet power spectrum of the millenniumlong PC1. The left axis is the Fourier period. The thick contour encloses regions of more than $95 \%$ confidence for a white-noise process. Hatched regions indicate the "cone of influence', where edge effects become important
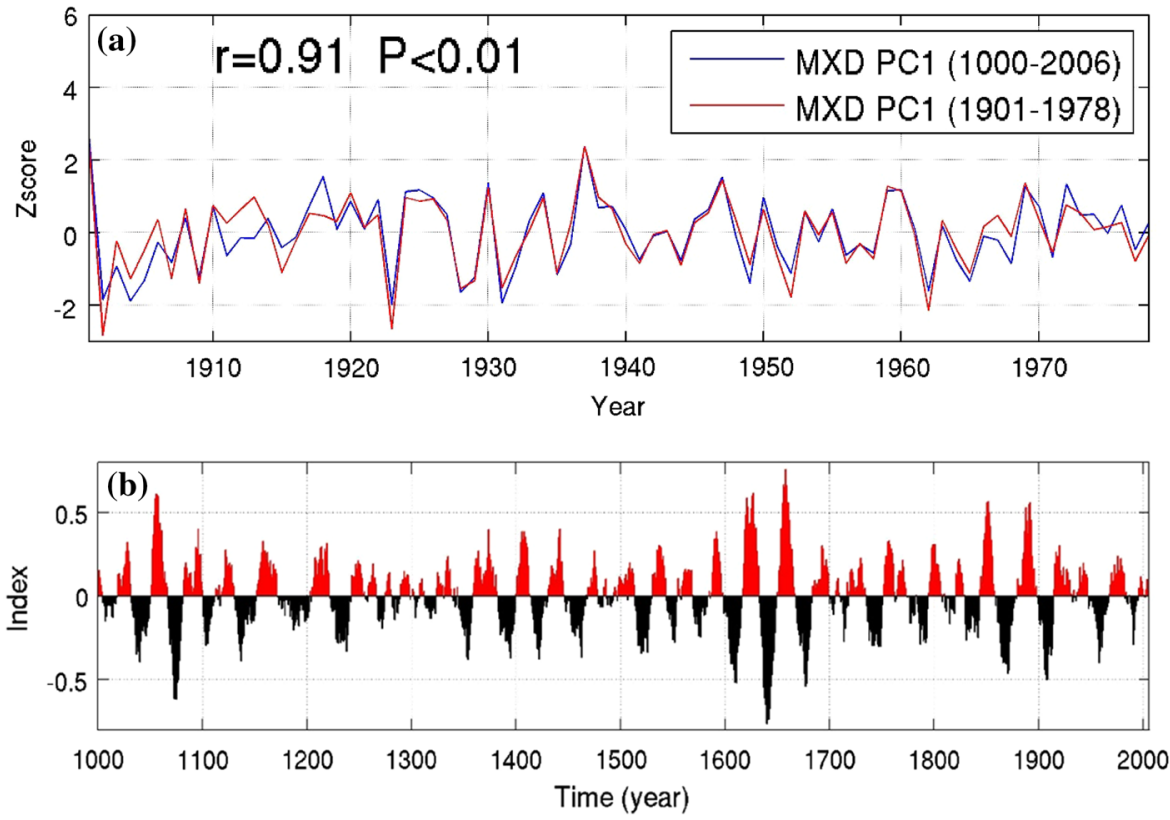

(c) Wavelet Power Spectrum

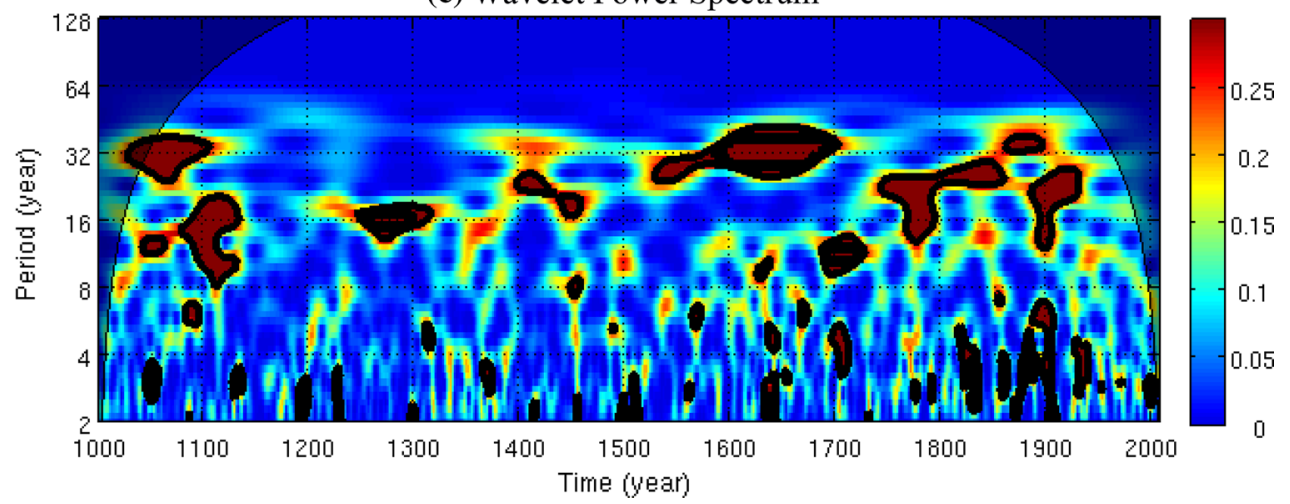

the Baltic Sea, the North Sea and the Norwegian Sea. SST can play an important role in regional climate via the interaction with large-scale climatic/oceanic modes of variability (e.g. the NAO and/or El Niño-Southern Oscillation (ENSO), Ionita et al. 2012, 2015; Schubert et al. 2014). When favorable phase conditions are met, both large-scale atmospheric as well as oceanic factors could act as precursors for extreme summers over Europe (Ionita et al. 2016). Thus, anticyclonic anomalies favor high SSTs around Fennoscandia through enhanced downward net radiative fluxes, but the high SSTs are also likely to play a role in enhancing TX90p by reducing the baroclinicity and thus reinforcing the anticyclonic circulation (Feudale and Shukla 2007, 2011a). Consequently, positive SST anomalies and increased frequency of TX90p are likely to occur simultaneously during summer. Figure $8 \mathrm{a}$ also indicates that the JJA warm-day extreme is associated with a positive center of SST anomalies over the eastern part of the North American continent. Feudale and Shukla (2011b) suggested that the configuration of the global SST might have forced a circulation pattern conducive to an anticyclonic circulation pattern in the European region. This SST teleconnection suggests an influence of the Gulf Stream on JJA warm-day extreme in Fennoscandia. However, previous studies have shown that European summer high-temperature extremes may also be influenced by mid-low latitude circulation anomalies (e.g. Cassou et al. 2005; Behera et al. 2013). Therefore, anomalous SST over the eastern part of the North American continent may also be caused by circulation anomalies associated with the changes of Rossby waves which could influence weather conditions at both the mid-latitude Atlantic and over the northern part of Europe. Figure 8b indicates that MXD PC1 is associated with the same positive-anomaly SST patterns as JJA warm-day extreme. However, MXD PC1 is also associated with strong negative SST anomalies over the southern part of Greenland, which is different from the patterns shown in Fig. 8a. This is consistent with the differences between 
the Z850 patterns shown in Fig. 7a, b, in which the Z850 pattern associated with MXD PC1 shows stronger and more extensive low-pressure anomalies over the southern part of Greenland compared to JJA warm-day extremes. An interesting feature of Fig. $8 \mathrm{~b}$ is the wave-train-like SST anomaly pattern over the North Atlantic Ocean, which also implies an influence of the propagation of oceanic and atmospheric circulation from low to high latitudes on the frequency of summer warm-day extremes over Fennoscandia.

In the Northern Hemisphere, anticyclonic circulation usually occurs at ridges located south of high-altitude wind flow (e.g. the jet stream) (Tsou and Smith 1990; Lupo and Smith 1995). Andrade et al. (2012) show that the meridional pressure gradient over Europe plays a key role in the occurrence of warm-day extreme events over Fennoscandia. The meridional pressure gradient over Europe is closely related to the North Atlantic polar jet streams (Bluestein 1992). Therefore, the occurrence of the summer high-temperature extremes in Fennoscandia is likely influenced by changes in jet stream configuration in this region. Figure 9a confirms that high TX90p summers are associated with enhanced (weakened) westerly zonal winds at $200 \mathrm{hPa}$ north (south) of Fennoscandia.

\section{Conclusions}

Based on the analysis above, the following conclusions can be drawn:

1. The Fennoscandian MXD PC1 can explain $50 \%$ of the variance of JJA warm-day extremes over the period 1901-1978, and is able to capture main features of atmospheric circulation and SST patterns associated with JJA warm-day extremes.

2. Frequent occurrences of JJA warm-day extremes are associated with an anomalous anticyclonic circulation pattern over northern Europe, an anomalously-high SST pattern over Baltic Sea, North Sea and Norwegian Sea, as well as an enhancement and a meridional shift of the northern mid-latitude jet stream.

3. The variability in tree-ring density can provide useful information about past summer high-temperature extremes and summer atmospheric circulation patterns over northern Europe beyond the instrumental period. The Fennoscandian MXD PC1 can be used to infer the variability of JJA warm-day extremes and their associated anticyclonic circulation pattern for the last millennium.

A next logical step is to identify the long-term changes of the Fennoscandian summer high-temperature extremes for the last millennium, and investigate the role of external forcings and internal variability in driving these changes, using both proxy and climate model data. We will also explore whether the linkages between tree-ring proxies and summer temperature extremes also exist in other regions.

Acknowledgements This study is promoted by Helmholtz funding through the Polar Regions and Coasts in the Changing Earth System (PACES) program of the AWI. Funding by the Helmholtz Climate Initiative REKLIM and the Excellence Cluster Marum (OC3 "The Ocean in the Earth System" High- and low-latitude atmosphere-ocean interactions) are gratefully acknowledged. HL was supported by the Swedish Science Council (VR, Grant \# 2015-04031). This research contributes to the strategic research area Modelling the Regional and Global Earth system (MERGE) and Biodiversity and Ecosystem services in a Changing Climate (BECC) and to the PAGES2 $\mathrm{K}$ initiative. We acknowledge the numerous researchers who have contributed their tree-ring data to the ITRDB (references in the supplementary material).

Open Access This article is distributed under the terms of the Creative Commons Attribution 4.0 International License (http://creativecommons.org/licenses/by/4.0/), which permits unrestricted use, distribution, and reproduction in any medium, provided you give appropriate credit to the original author(s) and the source, provide a link to the Creative Commons license, and indicate if changes were made.

\section{References}

Andrade C, Leite SM, Santos JA (2012) Temperature extremes in Europe: overview of their driving atmospheric patterns. Nat Hazards Earth Syst Sci 12(5):1671-1691

Antonsson K, Chen D, Seppä H (2008) Anticyclonic atmospheric circulation as an analogue for the warm and dry mid-Holocene summer climate in central Scandinavia. Clim Past 4:215-224

Battipaglia G, Frank D, Büntgen U, Dobrovolný P, Brázdil R, Pfister C, Esper J (2010) Five centuries of central European temperature extremes reconstructed from tree-ring density and documentary evidence. Glob Planet Change 72(3):182-191

Behera S, Ratnam JV, Masumoto Y, Yamagata T (2013) Origin of extreme summers in Europe: the Indo-Pacific connection. Clim Dyn 41(3-4):663-676

Björklund J (2014) Tree-rings and climate-Standardization, proxydevelopment, and Fennoscandian summer temperature history. $\mathrm{PhD}$ thesis, University of Gothenburg, Sweden. pp 11-12

Black E, Blackburn M, Harrison G, Hoskins B, Methven J (2004) Factors contributing to the summer 2003 European heatwave. Weather 59(8):217-223

Bluestein HB (1992) Synoptic-dynamic Meteorology in Midlatitudes: Observations and theory of weather systems, vol 2. Oxford University Press, New York, pp 378-382

Briffa KR, Jones PD (1993) Global surface air temperature variations during the twentieth century: part 2, implications for large-scale high-frequency palaeoclimatic studies. Holocene 3(1):77-88

Briffa KR, Jones PD, Bartholin TS, Eckstein D, Schweingruber FH, Karlén W, Zetterberg P, Eronen M (1992) Fennoscandian summers from AD 500: temperature changes on short and long timescales. Clim Dyn 7(3):111-119

Busuioc A, Chen D, Hellström C (2001) Temporal and spatial variability of precipitation in Sweden and its link with the large scale atmospheric circulation. Tellus 53A:348-367 
Carril AF, Gualdi S, Cherchi A, Navarra A (2008) Heatwaves in Europe: areas of homogeneous variability and links with the regional to large-scale atmospheric and SSTs anomalies. Clim Dyn 30(1):77-98

Cassou C, Terray L, Phillips AS (2005) Tropical Atlantic influence on European heat waves. J Clim 18(15):2805-2811

Chen D (2000) A monthly circulation climatology for Sweden and its application to a winter temperature case study. Int J Climatol 20(10):1067-1076

Chen D, Hellström C (1999) The influence of the North Atlantic oscillation on the regional temperature variability in Sweden: spatial and temporal variations. Tellus A 51(4):505-516

Chen D, Walther A, Moberg A, Jones PD, Jacobeit J, Lister D (2015) European trend Atlas of extreme temperature and precipitation. Springer, Dordrecht Heidelberg New York London, p 178. doi: 10.1007/978-94-017-9312-4

Ciais P, Reichstein M, Viovy N, Granier A, Ogée J, Allard V, Aubinet M, Buchmann N, Bernhofer C, Carrara A, Chevallier F, De Noblet N, Friend AD, Friedlingstein P, Grünwald T, Heinesch B, Keronen P, Knohl A, Krinner G, Loustau D, Manca G, Matteucci G, Miglietta F, Ourcival JM, Papale D, Pilegaard K, Rambal S, Seufert G, Soussana JF, Sanz MJ, Schulze ED, Vesala T, Valentini R (2005) Europe-wide reduction in primary productivity caused by the heat and drought in 2003. Nature 437(7058):529-533

Compo GP, Whitaker JS, Sardeshmukh PD (2006) Feasibility of a 100 year reanalysis using only surface pressure data. Bull Am Meteorol Soc 87:175-190. doi:10.1175/BAMS-87-2-175

Compo GP, Whitaker JS, Sardeshmukh PD, Matsui N, Allan RJ, Yin $\mathrm{X}$, Gleason BE, Vose RS, Rutledge G, Bessemoulin P, Brönnimann S, Brunet M, Crouthamel RI, Grant AN, Groisman PY, Jones PD, Kruk M, Kruger AC, Marshall GJ, Maugeri M, Mok HY, Nordli $\varnothing$, Ross TF, Trigo RM, Wang XL, Woodruff SD, Worley SJ (2011) The Twentieth Century Reanalysis Project. Q J Roy Meteorol Soc 137:1-28. doi:10.1002/qj.776

Conkey LE (1986) Red spruce tree-ring widths and densities in eastern North America as indicators of past climate. Quat Res 26(2):232-243

Cook ER, Peters K (1981) The smoothing spline: a new approach to standardizing forest interior tree-ring width series for dendroclimatic studies. Tree-ring Bull 41:45-66

Cornes RC, Jones PD (2013) How well does the ERA-Interim reanalysis replicate trends in extremes of surface temperature across Europe? J Geophys Res Atmos 118(18):10-262

De Bono A, Peduzzi P, Kluser S, Giuliani G (2004) Impacts of summer 2003 heat wave in Europe. Environ Alert Bull 2:1-4

Dima M, Lohmann G (2007) A hemispheric mechanism for the Atlantic multidecadal oscillation. J Clim 20(11):2706-2719

Donat MG, Alexander LV, Yang H, Durre I, Vose R, Dunn RJH, Willett KM, Aguilar E, Brunet M, Caesar J, Hewitson B, Jack C, Klein Tank AMG, Kruger AC, Marengo J, Peterson TC, Renom M, Oria Rojas C, Rusticucci M, Salinger J, Elrayah AS, Sekele SS, Srivastava AK, Trewin B, Villarroel C, Vincent LA, Zhai P, Zhang X, Kitching S (2013) Updated analyses of temperature and precipitation extreme indices since the beginning of the twentieth century: the HadEX2 dataset. J Geophys Res Atmos 118:2098-2118. doi:10.1002/jgrd.50150

Esper J, Büntgen U, Timonen M, Frank DC (2012a) Variability and extremes of northern Scandinavian summer temperatures over the past two millennia. Glob Planet Change 88:1-9

Esper J, Frank DC, Timonen M, Zorita E, Wilson RJ, Luterbacher J, Holzkämper S, Fischer N, Wagner S, Nievergelt D, Verstege A, Büntgen U (2012b) Orbital forcing of tree-ring data. Nat Clim Change 2(12):862-866

Feudale L, Shukla J (2007) Role of Mediterranean SST in enhancing the European heat wave of summer 2003. Geophys Res Lett 34(3):L03811
Feudale L, Shukla J (2011a) Influence of sea surface temperature on the European heat wave of 2003 summer. Part I: an observational study. Clim Dyn 36(9-10):1691-1703

Feudale L, Shukla J (2011b) Influence of sea surface temperature on the European heat wave of 2003 summer. Part II: a modeling study. Clim Dyn 36(9-10):1705-1715

Folland CK, Knight J, Linderholm HW, Fereday D, Ineson S, Hurrell JW (2009) The summer North Atlantic Oscillation: past, present, and future. J Clim 22(5):1082-1103

Fritts H (1976) Tree rings and climate. Academic Press, London, pp $55-152$

García-Herrera R, Díaz J, Trigo RM, Luterbacher J, Fischer EM (2010) A review of the European summer heat wave of 2003. Crit Rev Environ Sci Technol 40(4):267-306

Gouirand I, Linderholm HW, Moberg A, Wohlfarth B (2008) On the spatiotemporal characteristics of fennoscandian tree-ring based summer temperature reconstructions. Theor Appl Climatol 91(1-4):1-25

Grissino-Mayer HD, Fritts HC (1997) The international tree-ring data bank: an enhanced global database serving the global scientific community. The Holocene 7(2):235-238

Gunnarson BE, Linderholm HW, Moberg A (2011) Improving a treering reconstruction from west-central Scandinavia: 900 years of warm-season temperatures. Clim Dyn 36(1-2):97-108

Helama S, Vartiainen M, Holopainen J, Mäkelä HM, Kolström T, Meriläinen J (2014) A palaeotemperature record for the Finnish Lakeland based on microdensitometric variations in tree rings. Geochronometria 41(3):265-277

Horton DE, Johnson NC, Singh D, Swain DL, Rajaratnam B, Diffenbaugh NS (2015) Contribution of changes in atmospheric circulation patterns to extreme temperature trends. Nature 522(7557):465-469

Huang B, Banzon VF, Freeman E, Lawrimore J, Liu W, Peterson TC, Smith TM, Thorne PW, Woodruff SD, Zhang HM (2015) Extended reconstructed sea surface temperature version 4 (ERSST. v4). part I: upgrades and intercomparisons. J Clim 28(3):911-930

Hurrell JW (1995) Decadal trends in the North Atlantic oscillation: regional temperatures and precipitation. Science 269(5224):676-679

Ionita M, Lohmann G, Rimbu N, Chelcea S, Dima M (2012) Interannual to decadal summer drought variability over Europe and its relationship to global sea surface temperature. Clim Dyn 38:363-377. doi:10.1007/s00382-011-1028-y

Ionita M, Boronean C, Chelcea S (2015) Seasonal modes of dryness and wetness variability over Europe and their connections with large scale atmospheric circulation and global sea surface temperature. Clim Dyn. doi:10.1007/s00382-015-2508-2

Ionita M, Tallaksen LM, Kingston DG, Stagge JH, Laaha G, Van Lanen HAJ, Chelcea SM, Haslinger K (2016) The European 2015 drought from a climatological perspective. Hydrol Earth Syst Sci Discuss. doi:10.5194/hess-2016-218 (in review)

Irannezhad M, Chen D, Kløve B (2015) Interannual variations and trends in surface air temperature in Finland in relation to atmospheric circulation patterns, 1961-2011. Int J Climatol 35(10):3078-3092. doi:10.1002/joc.4193

Kovats RS, Kristie LE (2006) Heatwaves and public health in Europe. Eur J Public Health 16(6):592-599

Lamb HH (1950) Types and spells of weather around the year in the British Isles. Q J R Meteorol Soc 76:393-438

Linderholm HW (2006) Growing season changes in the last century. Agric For Meteorol 137(1):1-14

Linderholm HW, Gunnarson BE (2005) Summer temperature variability in central Scandinavia during the last 3600 years. Geografiska Annaler Ser A Phys Geogr 87(1):231-241

Linderholm HW, Walther A, Chen D (2008) Twentieth-century trends in the thermal growing season in the Greater Baltic Area. Clim Change 87(3-4):405-419 
Linderholm HW, Björklund JA, Seftigen K, Gunnarson BE, Grudd H, Jeong J-H, Drobyshevm I, Liu Y (2010) Dendroclimatology in Fennoscandia-from past accomplishments to future potential. Clim Past 6:93-114

Linderholm HW, Zhang P, Gunnarson BE, Björklund J, Farahat E, Fuentes M, Rocha E, Salo R, Seftigen K, Stridbeck P, Liu Y (2014) Growth dynamics of tree-line and lake-shore Scots pine (Pinus sylvestris L.) in the central Scandinavian Mountains during the medieval climate anomaly and the early little ice age. Front Ecol Evol 2:20

Linderholm HW, Björklund J, Seftigen K, Gunnarson BE, Fuentes M (2015) Fennoscandia revisited: a spatially improved tree-ring reconstruction of summer temperatures for the last 900 years. Clim Dyn 45(3):933-947

Liu W, Huang B, Thorne PW, Banzon VF, Zhang HM, Freeman E, Lawrimore J, Peterson TC, Smith TM, Woodruff SD (2015) Extended reconstructed sea surface temperature version 4 (ERSST. v4): part II. parametric and structural uncertainty estimations. J Clim 28(3):931-951

Lupo AR, Smith PJ (1995) Climatological features of blocking anticyclones in the Northern Hemisphere. Tellus A 47(4):439-456

Luterbacher J, Dietrich D, Xoplaki E, Grosjean M, Wanner H (2004) European seasonal and annual temperature variability, trends, and extremes since 1500. Science 303(5663):1499-1503

Maraun D, Kurths J (2004) Cross wavelet analysis: significance testing and pitfalls. Nonlinear Processes Geophysics 11(4):505-514

Maraun D, Kurths J, Holschneider M (2007) Nonstationary Gaussian processes in wavelet domain: synthesis, estimation and significance testing. Phys Rev E 75:016707

Melvin TM, Grudd H, Briffa KR (2013) Potential bias in 'updating' tree-ring chronologies using regional curve standardisation: reprocessing 1500 years of Torneträsk density and ring-width data. The Holocene 23(3):364-373

Moberg A, Jones PD, Lister D, Walther A, Brunet M, Jacobeit J, Alexander LV, Della-Marta PM, Luterbacher J, Yiou P, Chen D, Tank AMGK, Saladié O, Sigró J, Aguilar E, Alexandersson H, Almarza C, Auer I, Barriendos M, Begert M, Bergström H, Böhm R, Butler CJ, Caesar J, Drebs A, Founda D, Gerstengarbe FW, Micela G, Maugeri M, Österle H, Pandzic K, Petrakis M, Srnec L, Tolasz R, Tuomenvirta H, Werner PC, Linderholm H, Philipp A, Wanner H, Xoplaki E (2006) Indices for daily temperature and precipitation extremes in Europe analyzed for the period 1901-2000. Journal of Geophysical Research: Atmospheres (1984-2012). doi:10.1029/2006JD007103

Pfahl S (2014) Characterising the relationship between weather extremes in Europe and synoptic circulation features. Nat Hazards Earth Sys Sci 14(6):1461-1475
Rimbu N, Lohmann G, Ionita M (2014) Interannual to multidecadal Euro-Atlantic blocking variability during winter and its relationship with extreme low temperatures in Europe. J Geophys Res Atmos 119(24):13-621

Rocklöv V, Forsberg B (2008) The effect of temperature on mortality in Stockholm 1998-2003: a study of lag structures and heatwave effects. Scand J Public Health 36:516-523

Rogers JC (1997) North Atlantic storm track variability and its association to the North Atlantic oscillation and climate variability of northern Europe. J Clim 10(7):1635-1647

Schär C (2015) Climate extremes: the worst heat waves to come. Nat Clim Change. doi:10.1038/nclimate2864

Schubert S, Wang H, Koster RD, Suarez MJ, Groisman PY (2014) Northern Eurasian Heat Waves and Droughts. J Clim 27:3169-3207

Schweingruber FH, Bartholin T, Schaur E, Briffa KR (1988) Radiodensitometric-dendroclimatological conifer chronologies from Lapland (Scandinavia) and the Alps (Switzerland). Boreas 17(4):559-566

Seftigen K, Cook ER, Linderholm HW, Fuentes M, Björklund J (2015) The Potential of deriving tree-ring-based field reconstructions of droughts and pluvials over Fennoscandia. J Clim 28(9):3453-3471

Shepard D (1968) A two-dimensional interpolation function for irregularly spaced data. Paper presented at 23rd National Conference, Assoc. for Comput. Mach, New York

Torrence C, Compo GP (1998) A practical guide to wavelet analysis. Bull Am Meteorol Soc 79(1):61-78

Tsou CH, Smith PJ (1990) The role of synoptic/planetary-scale interactions during the development of a blocking anticyclone. Tellus A 42(1):174-193

Vandentorren S, Suzan F, Medina S, Pascal M, Maulpoix A, Cohen JC, Ledrans M (2004) Mortality in 13 French cities during the August 2003 heat wave. Am J Public Health 94(9):1518-1520

Von Storch H, Zwiers FW (2001) Statistical analysis in climate research. Cambridge University Press, Cambridge, pp 293-312

Whitaker JS, Compo GP, Wei X, Hamill TM (2004) Reanalysis without radiosondes using ensemble data assimilation. Mon Weather Rev 132:1190-1200. doi:10.1175/1520-0493(2004)

Xoplaki E, Luterbacher J, Paeth H, Dietrich D, Steiner N, Grosjean M, Wanner H (2005) European spring and autumn temperature variability and change of extremes over the last half millennium. Geophys Res Lett 32(15):L15713

Zhang P, Linderholm HW, Gunnarson BE, Björklund J, Chen D (2016) 1200 years of warm-season temperature variability in central Scandinavia inferred from tree-ring density. Clim Past 12:1297-1312 